\title{
TRANSFORMATION TO ECO-FRIENDLY CONSUMER GOODS PRODUCTION AND SUSTAINABLE GROWTH: A CASE OF UZBEKISTAN
}

\author{
Ashirali Abdirashidov* \\ Tashkent Islamic University under the Cabinet of Ministers of Uzbekistan, Tashkent, Uzbekistan
}

\begin{abstract}
The goal of this paper is to analyse consumers' behaviour, their attitudes towards eco-friendly products in conditions of Uzbekistan and identify any optimal solutions based on European experience. In definition of sustainable growth, along with other equally important aims of continuing development one may include the preservation of diverse eco-systems of a country. Giving up the nature for the sake of fast growth might lead to undesirable consequences, very much of it being experienced in wide range of emerging countries. One is government's efforts to encourage the standards with ecologically oriented quality control procedures by providing subsidies. There also might be protective measures limiting the waste produced by enterprises. This approach is called top-down approach. The other way is the bottom-up approach, where impact on consumers is created by state media or planned policy strategy promoting production of eco-friendly products. In my view, this is the long-term and most efficient approach where the desired result is achieved by the demand side.
\end{abstract}

Keywords: eco-friendly consumer goods, environmental conservation, sustainable growth, environmental policy

\section{Introduction}

Definition of sustainable growth demands balanced approach between high pace of growth and its longevity. At the same time, this includes a wider notion of welfare inclusiveness like eradication of poverty, improvement of employment market and environmental conservation. In context of a developing country, one may assume steady raise of income and new opportunity which lead to solution of two former, while the latter, environmental issue might be the high form of trap due to its lagged negative effects.

The case of Chinese economic growth and ecological situation in Beijing might be of good example for this. Numbers calculated by the Beijing Zhonglin Assets Appraisal show that Beijing's traffic congestion costs the city about $\$ 10$ billion a year in lost economic activity and around $\$ 7$ billion in terms of environmental damage (2014, Bloomberg). The smog in the air also affects tourism industry, with the number of visitors to Beijing dropping by 10 per cent in 2013. According to the Chinese Academy of Environmental Planning, the cost of the environmental damage to economy is estimated to around $\$ 9.3$ trillion, being equal to 3.5 per cent of GDP.

of course, once the problem is created, the solution might require even longer time. Quicker solution might be reachable for relatively richer part of population which might escape the disaster like two-thirds of the China's wealthy: those with assets of $\$ 1.6$ million or more, according to Bloomberg, have left or plan to leave the country citing environment as a main reason. However, the majority and subsequent generations might suffer from the negative effects of unbalanced economic growth. To avoid this fate, an emerging country must outline clear environmental policy which will not be a burden and at the same time preserves required nature for the well-being of nation.

Environmental aspect of sustainability is derived from business activities. It plays a key role in the well-being and development of cultures, cities, and the world. Without sustaining this key aspect, whether it is by land, sea or air, we would not be able to guarantee the safety of our future generations. That is why this topic is highly debated and often the outcome is non-agreeable amongst leaders, countries, and people. Even at the end of food chain we have to think about sustainability aspects while consuming food and using things (Paluchová and Benda Prokeinová, 2014).

\section{Material and methods}

To accomplish this goal, there are two major ways.

Conventional way is the top-down approach where government imposes particular restrictions and limits to enterprise's waste producing activity simultaneously restricting its economic potential. This approach is widely used and loses its effect as soon as any form of liberation in terms of the limits comes into play. Furthermore, though this approach might cover the production process itself, it might not direct the producer in making its final product which will be environmentally friendly used by households. Thus, the final goal of ecologically stable growth is undermined, though in paper it might look as measures are taken. The result of such policy in economic history of nations, in particular of that of the former Soviet Union demonstrates unwanted results like Aral Sea tragedy in present Uzbekistan.

\section{Research results}

Uzbekistan is a post-Soviet country gradually rebuilding its own economic infrastructure and currently demonstrating fast paces of economic growth. For the last decade, the average growth rate of GDP was around 8 per cent, reaching 8.1 in 2014 (2014, ADB Outlook), see figure 1.

Currently, its income level is a bit higher than in Vietnam and the country is considered in top ten countries in terms of gold, uranium and cotton production. There is no doubt that natural resources, rapid GDP growth and high number of population create a solid framework for considering Uzbekistan as an emerging market, interesting from the viewpoint of foreign direct investors, and also as a challenge for territorial expansion (Horská, 2014).

To carry out the above-mentioned approach, the government needs vast financial resources or at least good stream of tax revenue, to make sure 


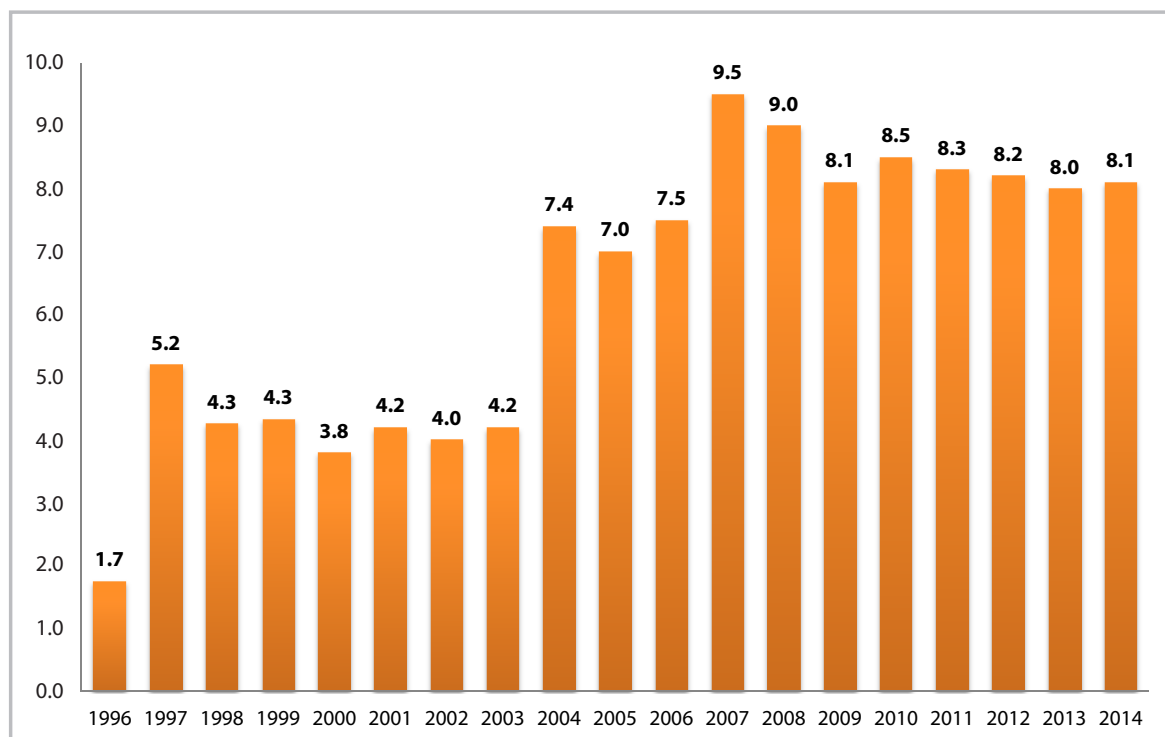

Figure 1 GDP growth rate of Uzbekistan in \% Source: Asian Development Outlook, 2014

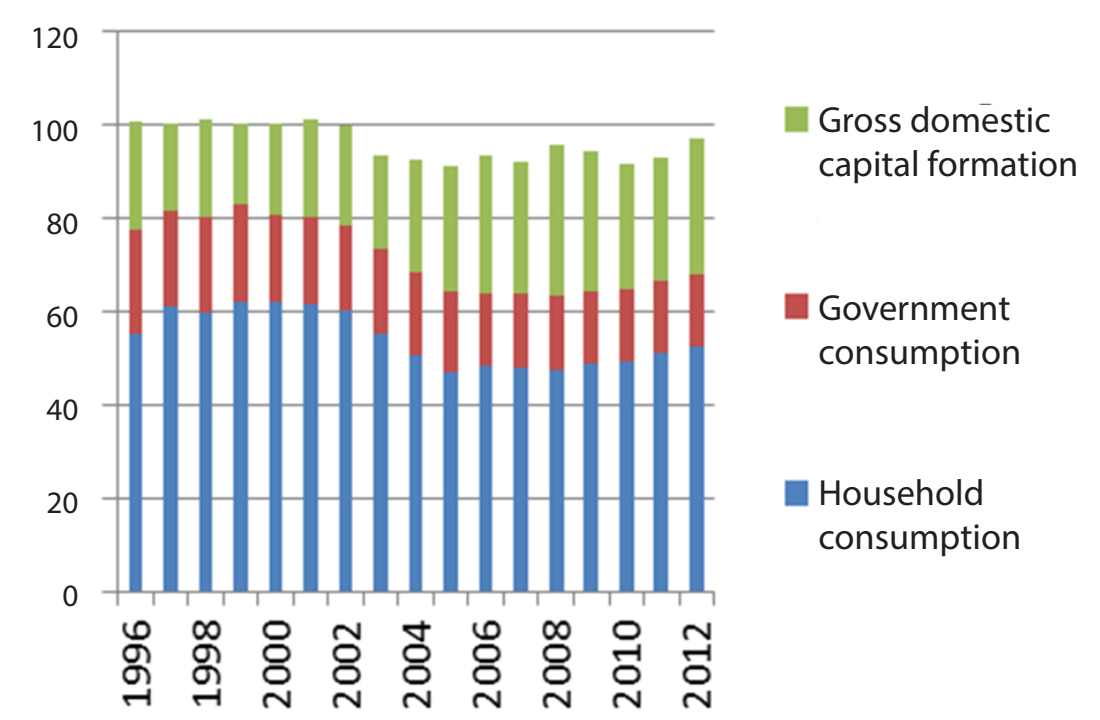

Figure 2 GDP structure of Uzbekistan Source: 2014. Asian Development Outlook 2014: Fiscal Policy for Inclusive Growth

that the loss which will occur due to restrictions will not cause a budget deficit leading to public debt problem similar to Greece. In this aspect, the fiscal position of Uzbekistan might not be ready due to almost purely tax financed budget (2014, ADB Outlook).

Otherwise the part of the budget currently spent on different types of expenditures must be cut off. However, one needs to keep in mind that Uzbekistan is one of the most socially oriented economies in Asia, topping second after Japan in terms of social security spending. (2013 ILO Database).

The other way is that of the bottom-up approach. In this approach, the opinions and taste of household steadily but firmly transforms into that of with environment in mind. Such transformation in paradigm causes the demand for ecologically friendly products to increase, affecting the production process and the final outcomes created by producers. Given the high level of household consumption share in GDP and steadily increasing income levels of households, this approach might work very well. (2014, ADB Outlook) (Figure 2)

In this aspect, it is important to consider the channels and context in which the following transformation will take place.

Provided that prevailing part of consumer goods are imported from abroad, this will impact the import choice causing adjustment in trading partners in the mid-term and long-term.
Current trend of trade turnover of Uzbekistan is characterized by high growth of China's share both in import and export, followed by Korea and Turkey.

The above-mentioned trend might reverse to the trade partners in the European Union which are notable for high standards of ecological and environmental standards. Furthermore, the trade partners might be involved in actual reverse process itself by providing technical assistance in frame of cooperation in shifting the households' perception of ecologically and environmentally friendly products to higher level.

Of course, it's vital to carry out similar reforms in agricultural sector which still constitutes around 20 per cent of Uzbekistan GDP and which is responsible for employment of around 27 per cent of labour force (2014, ASR Uzbekistan).

Finally, all the above-mentioned policy measures and reforms must be carried out with deep understanding of two-way effect, making sure that promotional measures are balanced with compensatory measures. In other way the reforms might not bring the desired effect at the end, which is to achieve sustainable growth which will not disturb the economic situation and provide the correct balance of ecological and environmental aspects of development through change in perception of consumer goods. "Green" concept and sustainability actions have to be a part of modern concept of business of developed and developing societies (Nagyová, 2014).

\section{Conclusion}

Economy of Uzbekistan with its high economic growth rate might as an emerging economy face environmental issues similar to those of China if consequent measures to tackle the balanced growth will not be taken. Analysing current state of Uzbekistan economy, we conclude that the bottom-up approach, affecting producers' behaviour through the change in households' perception might be a long-term solution of the problem. In this context, European experience can be very valuable which, if applied, might help to transform consumer behaviour to that of with better eco-friendliness standard and create higher demand for European trade partners.

\section{References}

ASIAN DEVELOPMENT OUTLOOK. 2014. Fiscal Policy for Inclusive Growth. http://www.adb.org/publications/ asian-development-outlook-2014-fiscal-policyinclusive-growth. Accessed March, 92015. 
BLOOMBERG BUSINESS. 2014. China Wakes Up to Its Environmental Catastrophe. http://www.bloomberg.com/bw/articles/2014-03-13/china-wakes-up-to-itsenvironmental-catastrophe. Accessed March, 102015.

Observatory of Economic Complexity. 2014. http://atlas.media.mit.edu/profile/country/ uzb/. Accessed March, 102015.

HORSKÁ, E. et al. 2014. International Marketing: Within and Beyond Visegrad Borders. Cracow : Wydawnictwo Episteme, 2014. 311 p. ISBN 978-83-7759-039-3.

NAGYOVÁ, L. et al. 2014. Marketing. Nitra : SUA, 459 p. ISBN 978-80-552-1269-2.

PALUCHOVÁ, J. - BENDA PROKEINOVÁ, R. 2014. Creation of responsible behavior and impact on sustainable customer buying behavior in retail sector. In Visegrad Journal on Bioeconomy and Sutainable Development, vol 3, 2014, no. 1, p. 39-45. ISSN 13393367.

STATE STATISTICAL COMMITTEE OF UZBEKISTAN. 2014. Annual Statistical Report.

INTERNATIONAL LABOR ORGANIZATION Database on Social Security Expenditure. 2013.

\section{Contact addresses}

${ }^{*}$ Ashirali Abdirashidov, Economics and Natural Sciences, Tashkent Islamic University under the Cabinet of Ministers of Uzbekistan, Faculty of Law, Department of International Economic Relations, A. Kadiriy Str. 11, Tashkent 100011, Uzbekistan 